\title{
Unidimensionality of the Scales of the Teacher Leadership Styles Inventory - TLSI
}

\author{
Ana Priscila Batista ${ }^{1}$ \\ Departamento de Psicologia da Universidade Estadual do Centro-Oeste, Irati, PR, Brazil \\ Lidia Natalia Dobrianskij Weber \\ Programa de Pós-Graduação em Educação, Universidade Federal do Paraná, \\ Curitiba, PR, Brazil \\ Plínio Marco de Toni \\ Departamento de Psicologia da Universidade Estadual do Centro-Oeste, Irati, PR, Brazil
}

\begin{abstract}
Exploratory factor analysis can be used to verify the unidimensionality of scales constructed to evaluate aspects related to specific dimensions of the teacher-student interaction. This study aimed to demonstrate the evaluation of unidimensionality for the three scales (Responsiveness, Demandingness and Coercive Control) of the Teacher Leadership Styles Inventory - TLSI, using exploratory factor analysis. Participants of the study were 113 students of the $4^{\text {th }}$ and $5^{\text {th }}$ years of elementary education, aged between 8 and 11 years, from public and private schools of cities in the state of Paraná. The 70 item TLSI was used. The application of the instrument was performed collectively with groups of no more than 25 students, in the classrooms. The results demonstrated the normal distribution of the data and that the scales that compose the TLSI are unidimensional. From the analysis of the factor loadings, the number of items in each scale was reduced: from 22 to 21 items in the Responsiveness scale, from 22 to 16 items in the Demandingness scale and from 26 to 19 items in the Coercive Control scale. Thus, the new version of the TLSI contained 56 items that showed factor loadings $>.3$.
\end{abstract}

Keywords: Unidimensionality, exploratory factor analysis, teacher-student interaction.

\section{Unidimensionalidade das Escalas do Inventário de Estilos de Liderança de Professores - IELP}

\section{Resumo}

A análise fatorial exploratória pode ser utilizada para verificar a unidimensionalidade de escalas construídas para avaliar aspectos referentes a dimensões específicas da interação professor-aluno. O presente trabalho teve como objetivo demonstrar a avaliação da unidimensionalidade para as três Escalas (Responsividade, Exigência e Controle Coercitivo) do Inventário de Estilos de Liderança de Professores - IELP, utilizando-se os recursos da análise fatorial exploratória. Participaram dessa pesquisa 113 alunos de $4^{\circ}$ e $5^{\circ}$ anos do Ensino Fundamental, com idade entre 8 e 11 anos, provenientes de escolas pública e privada de municípios do interior do Paraná. Foi utilizado o IELP com os 70 itens. A aplicação do instrumento foi coletiva com grupos de, no máximo, 25 alunos, em salas de aula. Nos resultados foi constatada a distribuição normal dos dados e que as escalas que compõem o IELP são unidimensionais. Em função da análise das cargas fatoriais, o número de itens em cada Escala foi reduzido: na Respon-

Mailing address: Universidade Estadual do Centro-Oeste, Departamento de Psicologia, Campus de Irati, PR 153 Km 7, Riozinho, Irati, PR, Brazil 84500-000. E-mail: anapribatista@yahoo.com.br 
sividade passou de 22 para 21 itens, na Exigência passou de 22 para 16 e na Escala Controle Coercitivo, passou de 26 para 19 itens. Dessa forma, a nova versão do IELP ficou com 56 itens que apresentaram carga fatorial $\geq 0,3$.

Palavras-chave: Unidimensionalidade, análise fatorial exploratória, interação professor-aluno.

\section{Unidimensionalidad de las Escalas del Inventario de Estilos de Liderazgo de Profesores - IELP}

\section{Resumen}

El análisis factorial exploratorio puede ser utilizado para averiguar la dimensionalidad de escalas construídas para evaluar aspectos relacionados a dimensiones específicas de la interacción profesoralumno. El presente trabajo tuvo como objetivo demostrar la evaluación de la unidimensionalidad para las tres Escalas (responsividad, exigencia y control coercitivo) del Inventario de Estilos de Liderazgo de Profesores - IELP, utilizándose los recursos del análisis factorial exploratorio. Participaron de esa investigación 113 alumnos de $4^{\circ}$ y $5^{\circ}$ años de la Enseñanza Fundamental, con edad entre 8 y 11 años, provenientes de escuelas pública y privada de municipios del interior de Paraná. Fue utilizado el IELP con 70 artículos. La aplicación del instrumento fue colectiva con grupos de, al máximo, 25 alumnos, en salones de clase. En los resultados fue contatada la distribución normal de los datos y que las escalas que componen el IELP son unidimensionales. En función de las cargas factoriales, el número de artículos en cada Escala fue reducido: en responsividad fue de 22 para 21 artículos, en Exigencia fue de 22 para 16 y en la Escala Control Coercitivo, fue de 26 para 19 artículos. De esta manera, la versión de IELP quedó con 56 artículos que presentaron carga factorial $\geq .3$.

Palabras clave: Unidimensionalidad, análisis factorial exploratório, interacción profesor-alumno.

The relationships established in childhood, in both the family and school contexts, are crucial for the development of the child. Specifically, the school, in addition to its role as a transmitter of academic content, is considered to be an important agent of socialization, an environment that can lead to both healthy development, as well as difficulties and problems that may impact on the life of an individual (Del Prette \& Del Prette, 2006; Hamre \& Pianta, 2006; Novak \& Pelaez, 2004). To comprehend the interactions in this environment, especially those established between the teacher and students, can help researchers and professionals working in education and mental health to think about effective prevention and intervention proposals for this context. Wubbels (2005) emphasizes that to understand these interactions is an important way to contribute to the prevention of behavioral problems in children, stress and burnout among teachers, as well as to assist in the professional development of the teachers.
Regarding this subject, it is clear, from the review of national studies performed by Batista (2013), that there is a need for studies on adaptation or construction and validation of national instruments directed toward the analysis of the teacher-student interaction in the early years of elementary education. In this stage, the teachers spend more time with their students, which significantly influences the behavior of those involved. Therefore, even though the teacher-student interaction is the subject of extensive research, there is still a need for studies on the adaptation or construction and validation of national instruments directed toward this analysis, from references and well operationalized concepts (Batista, 2013).

Regarding theoretical models and specific dimensions for analysis of the teacher-student interaction, Wentzel (2002) considers that socialization processes established by parents are robust and generalizable and can be used to describe ways in which teachers influence their 
students. The Parental Styles model proposed by Maccoby and Martin (1983) provides a good theoretical basis on which to base the analysis of the styles of teachers, considering that the dimensions "responsiveness" and "demandingness", analyzed by this model, are also present in the teacher-student interaction (Gill, Ashton, \& Algina, 2004; Pellerin, 2005; Walker, 2008). Furthermore, it is also important to evaluate "coercive control", with many studies performing this analysis, often also described as "conflict" (Birch \& Ladd, 1997; Hamre \& Pianta, 2006; Ladd \& Burgess, 2001; Pianta \& Steinberg, 1992).

Based on this literature and from the theoretical perspective of Behavior Analysis the Teacher Leadership Styles were outlined, with the analysis of the educational practices related to the early years of elementary education. These were defined as "a set of attitudes directed towards students, which, taken together, create an emotional climate in which behaviors are expressed, moderating the effectiveness of a particular practice and changing the responsiveness of the child in relation to the teachinglearning relationship" (Batista \& Weber, 2015, p. 28). The Responsiveness dimension refers to the behavior of the teacher regarding quality of communication, warmth, involvement, support, care, reciprocity and affection towards the students. The Demandingness dimension refers to the attitudes of teachers regarding establishing per-formance expectations, pressure, monitoring, supervision and control of the behavior of the students in order to impose limits and rules in the classroom and in the entire school environment. The Coercive Control dimension refers to the behavior of the teacher regarding the imposition of an aversive/ negative atmosphere in the classroom and in the school, using threats and punishment that is inappropriate for the behavior of pupils (Batista, 2013; Batista \& Weber, 2015).

From these theoretical constructs, Batista (2013) constructed the Teacher Leadership Styles Inventory - TLSI, which aims to identify these styles from items concerning situations/ behaviors of teachers related to the Responsive- ness, Demandingness and Coercive Control scales. The TLSI identifies the leadership styles of teachers of the $4^{\text {th }}$ and $5^{\text {th }}$ years of elementary education from items concerning situations/behaviors of teachers related to the Responsiveness, Demandingness and Coercive Control Scales. The instrument was constructed using theoretical and empirical procedures. Initially the theoretical constructs were defined and analyzed. Next, observations and interviews were performed for the design of the items, which were submitted to semantic analysis and content analysis. From this, the TLSI presented 22 items in the Responsiveness scale, 22 in the Demandingness scale and 26 in the Coercive Control scale, giving a total of 70 items.

Regarding the construction and analysis of the psychometric parameters, it is important to note that modern psychometrics presents two approaches: classical test theory (CTT) and item response theory (IRT). Classical test theory forms part of a unitary concept, with the involved parameters being behaviors, that is, the test tasks are defined according to other behaviors (present or future: the criterion) that the test aims to predict. Conversely, IRT is based on a dualistic concept of the human being. Thus, the test tasks are defined and are an effect of the aptitude or latent trait. The basic parameter of this type of instrument is the demonstration that the operationalization of the latent attribute in behaviors (items) actually corresponds to this attribute (Pasquali, 2003).

Thus, it can be observed that there are two test concepts, according to the theory adopted. However, although these two approaches present different concepts, generally a psychological instrument has characteristics that define the approach, with techniques belonging to the two theories often being used for the construction and analysis of the psychometric parameters. According to Toni, Romanelli and Salvo (2004), in psychological assessment instruments that evaluate unidimensional constructs, both based on CTT and on IRT, the unidimensionality of the assumption must be present, with the study of this characteristic being one of the main procedures in the 
psychometric analysis of an instrument and fundamental to estimate the other parameters.

The unidimensionality of the items of a test is important to verify "whether all the behaviors involved in the set refer to same thing" (Pasquali, 2007, p. 105), that is, a set of items measuring the same single construct (Pasquali, 2003). Pasquali (1999) states that to observe the unidimensionality of an instrument represents the first verification of the validity, as it refers to an analysis of the number of theoretical constructs measured by the test.

One way to verify the unidimensionality can be by means of factor analysis, which groups certain set of items into factors, and determines the loadings of each item on the factors (Hair, Anderson, Tatham \& Black, 2009). One of the uses of factor analysis regards the identification of the underlying dimensions of a domain of functioning assessed by the instrument (Floyd \& Widaman, 1995; Hogan, 2003/2006). According to Floyd and Widaman (1995), exploratory factor analysis is a common procedure for the development of measuring instruments, as it groups items into a single dimension, which corresponds to the theoretical construct related to the behaviors measured by the test items. That is, the factor analysis groups determined set of items into factors, which have a strong interrelationship indicating that they are measuring the same thing, thus demonstrating the unidimensionality.

Accordingly, exploratory factor analysis can also be used to verify the unidimensionality of scales constructed to evaluate aspects related to the specific dimensions of the teacher-student interaction. The present study aimed to demonstrate the evaluation of the psychometric parameter of unidimensionality for the three scales (Responsiveness, Demandingness and Coercive Control) of the Teacher Leadership Styles Inventory, using exploratory factor analysis.

\section{Method}

\section{Ethical Considerations}

The study was registered on the Plataforma Brasil, being submitted to and approved by the
Research Ethics Committee (CEP), under CEP authorization No. 247.389.

Initially, contact was made with the Municipal Education Departments of the participating cities to present the project and obtain authorization for the study from the person responsible. Next, the project was presented to the principals of public and private schools and the teachers of the first stage of elementary education, selected by convenience. A Terms of Consent (TC) form was delivered requesting permission to perform the study. The teachers forwarded to the parents or guardians of the students a TC form to read and sign if they agreed to the participation of their children in the study. Only those students whose parents signed the TC form and returned it to the researcher, answered the inventory, with this participation being voluntary.

\section{Participants}

Participants in this study were 113 students of the $4^{\text {th }}$ and $5^{\text {th }}$ years of elementary education, aged 8 and 11 years, from public and private schools of cities in the state of Paraná. The teachers and principals reported whether the children were literate, this being a requirement for participation.

Tables are presented below showing the distribution of data of the 113 participants regarding age and gender (Table 1), school year and school type (Table 2).

\section{Instruments}

For the data collection the 70 item TLSI (Batista, 2013) was used, according to the format obtained after semantic and content validity analysis, with 22 items in the Responsiveness Scale, 22 in the Demandingness scale and 26 in the Coercive Control scale, presented in scrambled form. The items are presented in written format, in appropriate language for the population. Some situations/behaviors of the teacher are described for each scale, on which students must mark an $\mathrm{X}$ in a square with regard to the frequency with which they appear: "Never or almost never", "Sometimes", or "always or almost always", which configures a three-point Likert scale. 
Table 1

Distribution of Data from Participants Regarding Age and Gender

\begin{tabular}{lccccccc}
\hline & & \multicolumn{2}{c}{ Gender } & & & \\
\cline { 3 - 4 } & & female & male & & Total & Percentage & Mean age Standard-deviation of age \\
& 8 & 13 & 15 & 28 & 24.8 & & \\
Age in years & 9 & 26 & 32 & 58 & 51.3 & 9.0 & .72 \\
& 10 & 12 & 14 & 26 & 23.0 & \\
Total & 11 & 01 & 00 & 01 & 0.9 & \\
Percentage & & 52 & 61 & 113 & 100 & \\
\hline
\end{tabular}

Table 2

Distribution of Data from Participants Regarding the School Year and Type of School

\begin{tabular}{|c|c|c|c|c|c|}
\hline & & \multicolumn{2}{|c|}{ Type of school } & \multirow{2}{*}{ Total } & \multirow{2}{*}{ Percentage } \\
\hline & & public & private & & \\
\hline \multirow{2}{*}{ School year } & $4^{\text {th }}$ year & 35 & 20 & 55 & 48.7 \\
\hline & $5^{\text {th }}$ year & 43 & 15 & 58 & 51.3 \\
\hline Total & & 78 & 35 & 113 & 100 \\
\hline Percentage & & 69 & 31 & 100 & \\
\hline
\end{tabular}

\section{Procedure}

The application of the instrument was carried out collectively with groups of no more than 25 students at a time, in a classroom of the school, during school hours. At the beginning of each application, the children were informed about the study, the guarantee of the confidentiality of the data, the voluntary nature of their participation and the need to not talk to each other while completing the instrument. The applications were conducted by the researcher, who, after providing the initial information, performed the reading of the TLSI: the general instructions, the example provided and each of the items, so that students responded concurrently. A trained person assisted in this process by monitoring the completion of the instrument by the students, passing out the folders and being available to answer questions. The time required for the application was approximately 30 minutes.

\section{Data Analysis}

The TLSI completed by each participant was marked according to the value proposed for each response of the participant to the three point Likert scale. The value 1 was attributed for "never or almost never", the value 2 for "Sometimes", and the value 3 for "always or almost always". With the sum of the values related to the responses of each participant to the items, the scores for each scale were obtained.

From this, analyzes were performed using the Statistical Package for the Social Sciences (SPSS), version for Windows, software. Initially the normality of the distribution of the survey data was verified, observing: (a) possible extreme values in the sample that could skew the normal distribution of the data, through analysis of a boxplot; (b) the Kolmogorov-Smirnov test, for which the $p$-value should be greater than .05 to indicate the normal distribution of the data; 
(c) the analysis of the histogram for observing the frequency distribution of the scores obtained, with the bell-shaped curve indicating normal distribution. After this, the unidimensionality of the set of items was analyzed for each scale of the TLSI. To check how much the set of items measured the same single construct/factor in each scale, exploratory factor analysis was used. Initially, to check whether the factor analysis would be appropriate, the Bartlett sphericity test was adopted, with $p$-value less than .05 being considered significant. The Kaiser-MeyerOlkin (KMO) index was also examined to verify the adequacy measure of the sample, with a minimum value of .60 for the factor analysis being considered adequate. To analyze the factor structure the main components method was used, analyzing the Scree Test and factor loadings, adopting the criterion of factor loadings equal to or higher than .30 for the inclusion of the items (Pasquali, 2003).

\section{Results and Discussion}

In order to verify the normal distribution of the data (of the scores obtained), the boxplot was first analyzed, to check for the presence of extreme values (outliers), which could compromise the interpretation of the data. Outliers, that is, extreme values, which may confuse the normal distribution of data, were not present in this graph. In the Histogram Graph, it was observed that the frequency of the data (scores) was distributed in a bell shape, or standard curve. Furthermore, in the Kolmogorov-Smirnov test, the $p$-value was greater than $.05(p=.174)$, which also indicates the normal distribution of the data. Thus, these data indicate the normal distribution of the data and, considering this, the use of parametric inferential statistical analysis was chosen to investigate the factor structure of the instrument.

To verify whether the factor analysis would be appropriate for each scale, the following were performed: (a) Bartlett's test of sphericity and (b) the Kaiser-Meyer-Olkin (KMO) index. The results of Bartlett's test of sphericity, with $p<$ .001 for the three scales, were considered perfect for the significance level of the analysis. This showed that significant correlations existed between the variables (Hair et al., 2009). The KMO index also demonstrated the adequacy of the sample, with values above .60 for the three scales (.76 for Responsiveness, .61 for Demandingness and .65 for Coercive Control).

After the analysis of these two coefficients for each of the scales, the exploratory factor analysis was carried out. The main components method was used, seeking the most appropriate number of factors for each scale, using the Scree Test criterion, which consists of a graph formed by the eigenvalues of the different factors plotted in descending order. According to Hair et al. (2009, p. 114), "the point at which the graph be-
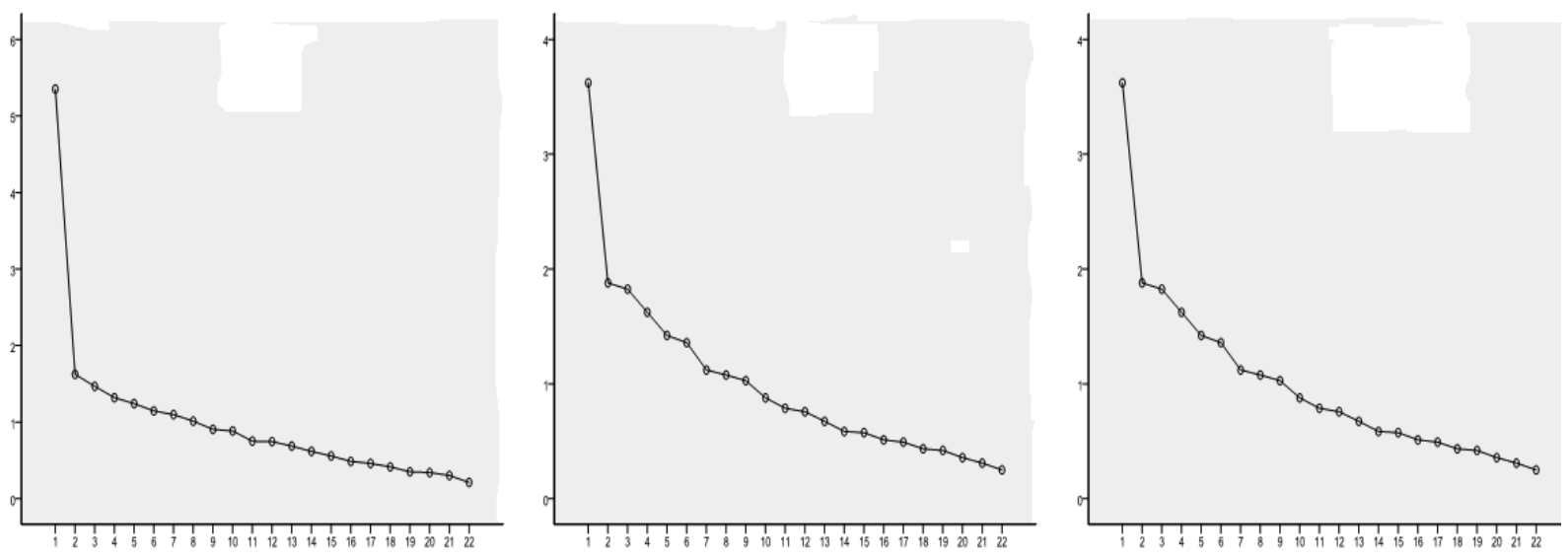

Figure 1. Eigenvalues ( $y$ axis) and number of components ( $x$ axis) of the Responsiveness ( $R$ ), Demandingness (D) and Coercive Control (CC) scales, respectively. 
gins to become horizontal is considered indicative of the maximum number of factors to be extracted". Figure 1 below presents the graphs with the results of the Scree Test for each scale.

The three graphs showed that the first factor was the one that presented the highest eigenvalue (24\% of the variance in Responsiveness Scale, $17 \%$ of the variance in the Demandingness scale, and $20 \%$ of the variance in the Coercive Control scale). In the graphs of the three scales there was a significant change of direction from the second factor, with little difference between the eigenvalues from this point, which was indicated by the less sloping line between these values compared to the line between the first and second factor.

With the analysis of the eigenvalues in the Scree Test and also analyzing the consistency between the items and the description of the theoretical construct that they represent, the extraction was performed of a single factor in each scale, with the factor loadings for each of the items being obtained, as can be seen in Tables 3, 4 and 5 .

Table 3

Factor Loadings of the Items of the Responsiveness Scale

Items of the Responsiveness Scale

Factor 1

66 - My teacher likes the students

59 - My teacher likes it when students are interested in new content

25 - My teacher gets along very well with the students

48 - My teacher tries to help when a student says he/she is having problems with the content

63 - All the students are important to my teacher

61 - My teacher pays attention to the opinions of the students

55 - My teacher explains again when the students pay attention, but do not understand the content

22 - My teacher praises the students when they behave themselves when he/she is not in the classroom

16 - My teacher praises the students when they behave well

31 - My teacher worries when a student is sick

50 - My teacher tries to help when a student says he/she is having problems at home

45 - My teacher tries to find out what happened when someone misses class

32 - When a student is behaving strangely, my teacher tries to find out what happened

5 - My teacher gives affection to the students

12 - My teacher praises the students when they get good grades

19 - My teacher tells the students to eat well

42 - My teacher asks the students what they did on vacation

39 - My teacher tries to find out what activities students do out of school

36 - My teacher asks the students what they do when they are at home

1 - My teacher is happy

7 - My teacher praises the students when they get an exercise right

27 - My teacher makes holds classes in other places, outside of the classroom

The factor loading of each item shows how representative the item is of its factor, indicating the correlation between the item and the theoretical construct it represents. Therefore, the higher the loading is, the greater the validity and representativity of the item. The criterion for inclusion/maintenance of the item was that it should present a factor loading of .30 or higher and, if many of the items did not present a high loading in the factor, the extraction of more 
Table 4

Factor Loadings of the Items of the Demandingness Scale

Items of the Demandingness Scale

Factor 1

20 - My teacher explains that it is important to follow the rules

57 - My teacher tells the students to be good mannered

6 - My teacher says what the rules are in the classroom

19 - My Teacher pressures the students to comply with the rules

60 - My teacher asks the students to be organized with their materials

67 - My teacher asks students to study more when their grades are bad

38 - My teacher agrees some rules with the students

69 - My teacher asks the students to do tasks well

62 - My teacher looks to see whether students are performing the activities that he/she sets during the class

24 - My teacher explains what happens to those who follow the rules

52 - When changing activity, my teacher explains what the students should do

35 - My teacher praises the students when they behave according to the rules

13 - My teacher says what the rules of the school are

28 - My teacher says what will happen if a student does not obey the rules

18 - When there is a presentation at school, my teacher asks the students to participate

37 - When the activity is in a group, my teacher says that everyone has to participate 30

41 - When a student does not obey the rules, my teacher carries out what he/she said would happen $\quad .26$

54 - My teacher asks the students to study $\quad .24$

33 - My teacher obeys the school rules $\quad .12$

46 - My teacher collects the homework $\quad .12$

3 - My teacher says how the students should do an activity $\quad .02$

9 - My teacher tells the students to improve their grades $\quad .01$

factors would be needed until the items were acceptably distributed (Pasquali, 2003).

Table 3 shows that the factor loadings of the items in the Responsiveness scale had values greater than .30 and that the only item $27 \mathrm{did}$ not present the factor loading criterion for inclusion (.08). Thus, this item was discarded and the others remained in this scale. In the Demandingness scale, the factor loadings of the items varied between .01 and .67 , with items 41,54 , 33, 46, 3 and 9 not presenting the factor loading criterion of .30 or higher for inclusion (Table 4). Finally, in the Coercive Control scale, the factor loadings of the items varied between .09 and .67 , with items 51, 64, 65, 4, 8, 14 and 44 not presenting the factor loading criterion for inclusion (Table 5). With this analysis, it was verified that the majority of the items were representative of the single extracted factor, that is, for each scale, it was not necessary to extract more factors.

From the analysis of the factor loadings, the number of items in each scale of the Teacher Leadership Styles Inventory was reduced: from 22 to 21 items in the Responsiveness scale, from 22 to 16 items in the Demandingness scale and from 26 to 19 items in the Coercive Control scale. Thus, the new version of the TLSI contained 56 items that presented factor loadings $\geq .3$.

It should be noted that the Demandingness dimension was the most heterogeneous of the three dimensions. The items of this scale refer to greater variability of behaviors of teachers, referring to both positive and aversive reinforcing contingencies, related to the establishment of performance expectations, pressure, monitoring, supervision and control of the behavior of stu- 
Table 5

Factor Loadings of the Items of the Coercive Control Scale

Items of the Coercive Control Scal

Factor 1

23 - My teacher blame a student without knowing what really happened

29 - My teacher says things to the students that they do not like

34 - When students do an exercise wrong, my teacher makes them feel bad

26 - My teacher seems angry with the students

40 - My teacher shouts

68 - My teacher takes away break times or physical education classes from students for any behavior

he/she thinks is wrong

56 - My teacher uses swear words

47 - My teacher is annoyed by everything that the students do

43 - My teacher scowls when the student is making any noise

70 - My teacher speaks badly about the students

15 - My teacher says that one student is better than another

17 - My teacher uses force to make students obey (e.g., hold the arm tightly, hits the hand on the table, throw things at the students)

21 - My teacher sends note to the parents for any behavior of the students that he/she thinks is wrong

30 - My teacher is always in a bad mood

2 - When a person comes into the classroom, my teacher speaks badly about the students in front of everyone

53 - My teacher lets the other students curse a student

58 - My teacher makes fun of the students

11 - My teacher humiliates the students

49 - My teacher punishes those who do not do the task

51 - My teacher tells the entire class who got the best and the worst grades

64 - My teacher calls the principal to solve any problem

65 - My teacher does nothing when the students are fighting

4 - My teacher threatens the students to make them to do what he/she wants $\quad .17$

8 - My teacher does not care when a student tries to do something right $\quad .13$

14 - My teacher punishes the whole class because of the misbehavior of a few students $\quad .10$

44 - My teacher gets angry when he/she is explaining the content and the students ask about something else .09

dents in order to impose limits and rules in the classroom and in the entire school environment. This may have influenced the factor loadings obtained by the items, indicating that some were not representative of the construct, with these being excluded. Therefore, this dimension was left with fewer items. The Responsiveness and Coercive Control scales refer, in a certain way, to more homogeneous contingencies. In the first contingencies of positive reinforcement predominate and in the second contingencies of punish- ment and negative reinforcement that occur in an intense and oppressive way, unwarranted and/or independent of an established rule, related much more to the teacher than the student (Batista \& Weber, 2015).

\section{Final Considerations}

This study aimed to evaluate the psychometric parameter of unidimensionality for the three scales (Responsiveness, Demandingness 
and Coercive Control) of the Teacher Leadership Styles Inventory. This instrument proposes to identify the leadership styles of teachers of the $4^{\text {th }}$ and $5^{\text {th }}$ years of elementary education from items regarding situations/behaviors of the teachers related to the Responsiveness, Demandingness and Coercive Control scales.

Analysis of the unidimensionality, using exploratory factor analysis, indicated the presence of a single factor for each of the scales that make up the TLSI, demonstrating that all the items of each scale are representative of the construct they represent. This was initially projected, given that the instrument was constructed based on theoretically well-defined constructs. The three scales of the TLSI involve behaviors of teachers that should be evaluated as they may influence the behavior of students and simultaneously be influenced by many variables.

The TLSI is an important instrument to evaluate the teacher-student interaction, with no similar instruments being found. Batista (2013) showed that, in the national literature, there are few instruments constructed and validated to evaluate the teacher-student interaction in elementary education. Regarding the international literature, the use of scales and self-report instruments was found, however, in the majority of cases it was the teachers that responded, with the interaction evaluated from the adult perspective, unlike the TLSI, in which students are the respondents. When the teachers are the respondents, they may be more under the control of other variables than under the control of their behavior in the interaction with the students themselves, for example, giving more socially acceptable answers. It is important to investigate the concept of the child regarding the interaction with the teacher, since this interaction can influence various aspects of childhood development.

The result obtained emphasize the importance of performing further studies on the psychometric properties of the TLSI, as this instrument is presented as a possible tool that can be used both in research and in the practice of education professionals and school/educational psychologists.

\section{References}

Batista, A. P. (2013). Construção e análise de parâmetros psicométricos do Inventário de Estilos de Liderança de Professores (Doctoral dissertation, Setor de Educação, Universidade Federal do Paraná, Curitiba, PR, Brazil).

Batista, A. P., \& Weber, L. N. D. (2015). Professores e estilos de liderança: Manual para identificálos e modelo teórico para compreendê-los. $\mathrm{Cu}-$ ritiba, PR: Juruá.

Birch, S. H., \& Ladd, G. W. (1997). The teacher-child relationship and children's early school adjustment. Journal of School Psychology, 35(1), 6179. doi:10.1016/S0022-4405(96)00029-5

Del Prette, Z. A. P., \& Del Prette, A. (2006). Treinamento de habilidades sociais na escola: O método vivencial e a participação do professor. In M. Bandeira, Z. A. P. Del Prette, \& A. Del Prette (Eds.), Estudos sobre habilidades sociais e relacionamento interpessoal (pp. 143-160). São Paulo, SP: Casa do Psicólogo.

Floyd, F. J., \& Widaman, K. F. (1995). Factor analysis in the development and refinement of clinical assessment instruments. Psychological Assessment, 7(3), 286-299. doi:10.1037/10403590.7.3.286

Gill, M. G., Ashton, P., \& Algina, J. (2004). Authoritative schools: A test of a model to resolve the school effectiveness debate. Contemporary Educational Psychology, 29, 389-409. doi:10.1016/j. cedpsych.2003.10.002

Hair, J. F., Anderson, R. E., Tatham, R. L., \& Black, W. C. (2009). Análise multivariada de dados $\left(6^{\text {th }}\right.$ ed.). Porto Alegre, RS: Bookman.

Hamre, B. K., \& Pianta, R. C. (2006). Student-teacher relationships. In G. G. Bear \& K. M. Minke (Eds.), Children's needs II: Development, prevention and intervention (pp. 49-60). Bethesda, MD: National Association of School Psychologists.

Hogan, T. P. (2006). Introdução à prática de testes psicológicos (L. A. F. Pontes, Trans.). Rio de Janeiro, RJ: LTC. (Original work published 2003)

Ladd, G. W., \& Burgess, K. B. (2001). Do relational risks and protective factors moderate the linkages between childhood aggression and early psychological and school adjustment? Child Development, 72, 1579-1601. doi:10.1111/14678624.00366 
Maccoby, E., \& Martin, J. (1983). Socialization in the context of the family: Parent-child interaction. In E. M. Hetherington (Ed.), Socialization, personality, and social development (pp. 1-101). New York: Wiley.

Novak, G., \& Pelaez, M. (2004). Child and adolescent development: A behavioral systems approach. Thousand Oaks, CA: Sage.

Pasquali, L. (2003). Psicometria: Teoria dos testes na psicologia e na educação. Petrópolis, RJ: Vozes.

Pasquali, L. (2007). Validade dos testes psicológicos: Será possível reencontrar o caminho? Psicologia: Teoria e Pesquisa, 23, 99-107. doi:10.1590/ S0102-37722007000400019

Pasquali, L. (Ed.). (1999). Instrumentos psicológicos: Manual prático de elaboração. Brasília, DF: Laboratório de Pesquisa em Avaliação e Medida.

Pellerin, L. A. (2005). Applying Baumrinds parenting typology to high schools: Toward a middle-range theory of authoritative socialization. Social Science Research, 34, 283-303. doi:10.1016/j.ssresearch.2004.02.003

Pianta, R. C., \& Steinberg, M. (1992). Teacher-child relationships and the process of adjusting to school. New Directions for Child Development, 57, 61-80. doi:10.1002/cd.23219925706
Toni, P. M., Romanelli, E. J., \& Salvo, C. G. (2004). Análise da estrutura fatorial da Bateria PiagetHead. Boletim de Psicologia, 54(120), 73-86.

Walker, J. M. T. (2008). Looking at teacher practices through the lens of parenting style. The Journal of Experimental Education, 76(2), 218-240. doi:10.3200/JEXE.76.2.218-240

Wentzel, K. R. (2002). Are effective teachers like good parents? Teaching styles and student adjustment in early adolescence. Child Development, 73(1), 287-301.

Wubbels, T. (2005). Student perceptions of teacherstudent relationships in class [Editorial]. International Journal of Educational Research, 43, $1-5$.
Recebido: 21/10/2014

$1^{a}$ revisão: $12 / 05 / 2015$

$2^{a}$ revisão: $24 / 07 / 2015$

Aceite final: 13/08/2015 